\title{
Efektifitas Model Pembelajaran Kooperatif Tipe Teams Games Tournament Untuk Meningkatkan Hasil Belajar
}

\author{
${ }^{1}$ Mukminah, ${ }^{2}$ Eka Fitriani, ${ }^{3}$ Mahsup, ${ }^{4}$ Syaharuddin \\ ${ }^{1}$ SMA Syifaunnufus Bayan Lombok Utara \\ ${ }^{3.4}$ Pendidikan Matematika, Universitas Muhammadiyah Mataram, Indonesia \\ ${ }^{2}$ Universitas Muhammadiyah Mataram, Indonesia \\ minah@gmail.com, supyeka@gmail.com, ekaabata88@gmail.com, syaharuddin.ntb@gmail.com
}

\begin{tabular}{l} 
ARTICLE INFO \\
\hline Article History: \\
Received : $08-09-2019$ \\
Revised : $12-11-2019$ \\
Accepted : 15-11-2019 \\
Online : 25-11-2019 \\
Keywords: \\
Efektifitas; Teams Games \\
Tournament; \\
Belajar
\end{tabular}

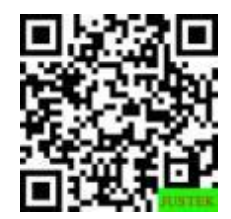

\begin{abstract}
Abstract: Penelitian ini bertujuan untuk mengetahui Efektifitas Model Pembelajaran Kooperatif Tipe Teams Games Tournament (TGT) Untuk meningkatkan Hasil Belajar Matematika Siswa Kelas XI IPS SMA Negeri 8 Mataram. Penelitian ini termasuk dalam penelitian Quasi Experimental Design. Populasi penelitian ini mencakup seluruh siswa kelas XI IPS SMA Negeri 8 Mataram yang terdiri dari 4 kelas kemudian dimbil secara acak, dua kelas dari jumlah populasi yaitu XI IPS 3 (kelas Eksperimen) dan XI IPS 2 (Kelas Kontrol) sebagai sampel penelitian. Instrumen dalam penelitian ini berupa soal uraian yang sudah divalidasi. Berdasarkan hasil penelitian diperoleh kemampuan awal siswa untuk kedua kelompok (kelompok eksperimen dan kelompok kontrol) adalah homogen yang ditunjukkan dengan Fhitung < Ftabel (1,06 < 1,72). Dan pada tes kemampuan akhir (setelah perlakuan) diperoleh thitung < ttabel (1.626 < 2,000), sehingga yang diterima adalah $\mathrm{HO}$ yang berarti model pembelajaran kooperatif tipe teams games tournament (TGT) tidak efektif untuk meningkatkan hasil belajar matematika materi program linear siswa kelas XI IPS SMA Negeri 8 Mataram.
\end{abstract}

\begin{abstract}
Abstrak: Penelitian ini bertujuan untuk mengetahui Efektifitas Model Pembelajaran Kooperatif Tipe Teams Games Tournament (TGT) Untuk meningkatkan Hasil Belajar Matematika Siswa Kelas XI IPS SMA Negeri 8 Mataram. Penelitian ini termasuk dalam penelitian Quasi Experimental Design. Populasi penelitian ini mencakup seluruh siswa kelas XI IPS SMA Negeri 8 Mataram yang terdiri dari 4 kelas kemudian dimbil secara acak, dua kelas dari jumlah populasi yaitu XI IPS 3 (kelas Eksperimen) dan XI IPS 2 (Kelas Kontrol) sebagai sampel penelitian. Instrumen dalam penelitian ini berupa soal uraian yang sudah divalidasi. Berdasarkan hasil penelitian diperoleh kemampuan awal siswa untuk kedua kelompok (kelompok eksperimen dan kelompok kontrol) adalah homogen yang ditunjukkan dengan $\mathrm{F}_{\text {hitung }}<\mathrm{F}_{\text {tabel }}(1,06<$ 1,72). Dan pada tes kemampuan akhir (setelah perlakuan) diperoleh thitung $<\mathrm{t}_{\text {tabel }}(1.626<2,000)$, sehingga yang diterima adalah $\mathrm{H}_{0}$ yang berarti model pembelajaran kooperatif tipe teams games tournament (TGT) tidak efektif untuk meningkatkan hasil belajar matematika materi program linear siswa kelas XI IPS SMA Negeri 8 Mataram.
\end{abstract}

\section{A. LATAR BELAKANG}

Pendidikan nasional berfungsi mengembangkan kemampuan dan membentuk 
watak serta peradaban bangsa yang bermartabat dalam rangka mencerdaskan kehidupan bangsa (Undang-Undang Republik Indonesia, 2003)(Mahsup \& Anwar, 2020). Pendidikan bertujuan untuk mengembangkan potensi peserta didik agar menjadi manusia yang beriman dan bertakwa kepada Tuhan Yang Maha Esa, berakhlak mulia, sehat, berilmu, cakap, kreatif, dan menjadi warga Negara yang demokratis serta bertanggung jawab (UURI, 2003)(Adriyanto, Dewi Pramita, Abdillah, Syaharuddin, Mahsup, 2019). Pendidikan diartikan sebagai usaha manusia untuk membina kepribadiannya sesuai dengan nilainilai di dalam masyarakat dan kebudayaan dalam perkembangannya (Puspita, Slameto, \& ..., 2018)(Muhardini et al., 2020)(Eka Fitriani, 2018). Pendidkan merupakan hal yang sangat dibutuhkan dalam kehidupan sehari-hari, banyak hal yang diperoleh dari pendidikan, baik tentang keterampilan, kepribadian, nilai bersikap, pengetahuan dan lain sebagainya (Mandailina \& Mahsup, 2018)(Mahsup, Ibrahim, Muhardini, Nurjannah, \& Fitriani, 2020). Pemerintah telah melakukan berbagai usaha untuk meningkatkan mutu pendidikan (Mahsup, Abdillah, 2018)(Eka Fitriani, 2018). Usaha yang dilakukan pemerintah dalam meningkatkan mutu pendidikan tidak terlepas dari program pendidikan yang sangat penting dan mendasar bagi kemajuan bangsa Indonesia (Habib Ratu Putra Negara, Syaharuddin Syaharuddin, Kiki Riska Ayu Kurniawati, 2019)(Mahsup, 2011). Usaha yang dilakukan pemerintah diantaranya usaha untuk meningkatkan suasana belajar yang lebih kondusif (Mahsup \& Anwar, 2020)(Nurfiati, Vera Mandailina, Mahsup, Syaharuddin, 2020)Bukan itu saja, pemerintah juga melakukan berbagai inovasi dalam penerapan model pembelajaran. Kedua usaha tersebut dimaksudkan untuk mencapai hasil belajar yang lebih baik dari sebelumnya (Arta Diantoro, Mahsup, \& Pramita, 2019)(Mahsup \& Anwar, 2020).

Upaya untuk meningkatkan mutu pendidikan harus dilakukan dengan menggerakan seluruh komponen dalam pendidikan (Aribawati, Kristin, \& ..., 2018)(Mahsup, 2011). Salah satu aspek yang harus ditingkatkan yaitu proses belajar mengajar (Setyowati, Kristin, \& Anugraheni, 2018)(Rahmatin, Pramita, Sirajuddin, \& Mahsup, 2019)(Mahsup \& Anwar, 2020). Dalam proses pembelajaran seharusnya siswa dilibatkan secara langsung didalam pembelajaran sehingga siswa dapat mengembangkan pengetahuan, daya berpikir dan kemampuannya (Murtiah, 2018)(Mahsup \& Anwar, 2020). Penggunaan model dan metode pembelajaran yang tepat akan turut menentukan efektifitas dan efesiensi pembelajaran (Setyowati et al., 2018)(Puspita et al., 2018)(Mahsup \& Anwar, 2020). Salah satu model pembelajaran yang dapat digunakan untuk meningkatkan hasil belajar siswa adalah model pembelajaran kooperatif tipe teams games tournament.

Adapun kelebihan model tipe teams games tournament yaitu (1) pembelajaran lebih menarik perhatian peserta didik sehingga dapat menumbuhkan motivasi belajar; (2) pembelajaran menjadi lebih jelas dan bermakna, sehingga dapat dipahami oleh peserta didik; (3) metode megajar akan lebih bervariasi, tidak semata-mata komunikasi verbal atau ceramah melalui penuturan kata-kata oleh guru, sehingga peserta didik tidak merasa jenuh, bosan, dan guru tidak kehabisan tenaga; (4) peserta didik dapat lebih banyak melakukan kegiatan belajar sebab tidak hanya mendengarkan uraian guru, tetapi juga aktivitas lain seperti mengamati, melakukan, memerankan, dan mendemonstrasikan (Sulfemi, 2018). Dalam pengimplementasian model pembelajaran tames games tournament (TGT) ini menggunakan istilah tournament akademik, yaitu menggunakan kuis-kuis dan sistem skor kemajuan individu, dimana para siswa berlomba sebagai wakil tim mereka dengan anggota tim lain untuk mengumpulkan skor terbanyak (Sulfemi, 2018)(Mahsup \& Anwar, 2020). 


\section{B. METODE PENELITIAN}

Metode yang digunakan dalam penelitian ini adalah kuantitatif dengan pendekatan Quasi experimental design. Bentuk desain eksperiment ini merupakan pengembangan dari true experimental design, yang sulit dilaksanakan (Arikunto, 2006). Desain ini mempunyai kelompok kontrol, tetapi tidak dapat berfungsi sepenuhnya untuk mengontrol variabel-variabel luar yang mempengaruhi pelaksanaan eksperiment. populasi dalam penelitian ini adalah seluruh siswa kelas XI IPS semester ganjil SMA Negeri 8 mataram tahun pelajaran 2014/2015. Populasi siswa kelas XI IPS di SMAN 8 Mataram berjumlah 4 (empat) kelas yaitu kelas XI IPS 1 dengan jumlah siswa 40 orang, XI IPS 2 sebanyak 37 orang, XI IPS 3 sebanyak 36 orang dan XI IPS 4 sebanyak 38 orang. Pengambilan sampel dalam penelitian ini dengan cara simple random sampling yaitu pengambilan sampel dilakukan tanpa memperhatikan strata dalam populasi itu. Sampel yang diambil yaitu dua kelas yang terdiri dari satu kelas eksperiment yaitu kelas XI IPS 3 yang akan mendapat perlakuan dengan model pembelajaran kooperatif tipe teams games tournament (TGT) dan satu kelas kontrol yaitu kelas XI IPS 2 yang akan mendapatkan perlakuan dengan pembelajaran konvensional (ceramah dan latihan).

Variabel dalam penelitian ini terdiri dari dua variabel bebas (independen) dan satu variabel terikat (dependen). Variabel bebas dalam penelitian ini adalah model pembelajaran kooperatif tipe teams games tournament (TGT) dan model pembelajaran konvensional (ceramah dan latihan), sedangkan variabel terikat dalam penelitian ini adalah hasil belajar siswa. Instrument yang digunakan dalam penelitian ini adalah tes hasil belajar siswa, instrument untuk mengukur hasil belajar siswa yang digunakan adalah tes uraian. Instrument tes ini digunakan untuk mengukur hasil belajar siswa baik sebelum perlakuan (pretest) maupun sesudah perlakuan (posttest) selanjutnya skor hasil belajar siswa digunakan untuk mengetahui pengaruh model pembelajaran kooperatif tipe teams games tournament (TGT).

\section{HASIL DAN PEMBAHASAN}

Pada tahap awal penelitian, sebagai rujukan untuk mengetahui kemampuan awal siswa dalam penelitian ini adalah nilai pretest yang diberikan sebelum perlakuan. Kemudian dihitung nilai rata-rata masing-masing kelas untuk menentukan kelas kontrol dan eksperiment. Dari analisis nilai pretest di peroleh nilai rata-rata kelas XI IPS 2 sebesar 29,57 dan nilai rata-rata kelas XI IPS 3 adalah 31,64. Hal ini menunjukkan bahwa tidak terdapat perbedaan hasil belajar yang signifikan antara kedua kelompok. Dapat juga dikatakan bahwa kedua kelompok berada dalam keadaan yang sama atau homogen. Berdasarkan hal tersebut maka dipilih kelas XI IPS 3 sebagai kelas eksperiment dan kelas XI IPS 2 sebagai kelas kontrol. Kemudian kedua kelas diberi perlakuan berbeda, kelas eksperiment diajar menggunakan model pembelajaran kooperatif tipe teams games tournament (TGT) sedangkan kelas kontrol diajar dengan metode konvensional. Setelah diberikan perlakuan, kemudian diberikan tes hasil belajar/posttest. Dari data posttest tersebut diperoleh nilai rata-rata kelas kontrol (XI IPS 2) adalah 63,22 sedangkan nilai rata-rata kelas eksperiment (XI IPS 3) sebesar 67,17 . Selanjutnya dilakukan uji normalitas untuk kelas kontrol dan kelas eksperiment. Berdasarkan hasil perhitungan diperoleh bahwa data kedua kelas adalah berdistribusi normal. Begitu pula pada uji homogenitas diketahui bahwa kedua kelas memiliki varians yang homogeny. Pada uji hipotesis diperoleh thitung $=1,626$ dan tabel $=2.000$. Karena thitung $<t_{\text {tabel }}(1,626<2,000)$ maka $\mathrm{H}_{0}$ diterima dan $\mathrm{H}_{\mathrm{a}}$ ditolak. Hal ini menunjukkan bahwa tidak terdapat perbedaan hasil belajar matematika antara siswa yang diajar 
dengan menggunakan model pembelajaran kooperatif tipe teams games tournament (TGT) dengan siswa yang diajar dengan menggunakan metode konvensional (ceramah dan latihan).

Pembelajaran kelas eksperiment diterapkan dengan menggunakan model pembelajaran kooperatif tipe teams games tournament (TGT). Penerapan model pembelajaran kooperatif tipe teams games tournament (TGT) pada jenjang sekolah menengah lebih menekan pada pengembangan kecakapan personal dan kecakapan sosial. Dalam penerapan model pembelajaran kooperatif tipe teams games taournament (TGT) ini seluruh siswa dikelompokkan menjadi tujuh kelompok yang masing-masing kelompok terdiri dari 5 orang. Pengelompokan siswa dilakukan secara heterogen, yaitu tidak memperhatikan kemampuan, jenis kelamin, suku atau ras. Dengan adanya heterogenitas anggota kelompok tersebut diharapkan dapat memotivasi siswa untuk saling membantu. Akan tetapi, masih ada siswa dari tiap-tiap kelompok yang tidak ingin membantu anggota yang lain dalam mengerjakan tugas kelompok, siswa yang lambat berpikir atau yang memiliki kemampuan rendah masih bergantung pada siswa yang berkemampuan tinggi, dan siswa yang berkemampuan tinggi tersebut juga kurang terbiasa dan sulit memberikan penjelasan kepada anggota kelompok yang lain. Dengan kata lain, kerjasama antar anggota kelompok masih belum maksimal.

Turnamen akademik (games tournament) yang merupakan bagian terpenting dari model pembelajaran kooperatif tipe teams games tournament (TGT) ini bertujuan untuk memotivasi siswa untuk lebih bekerja keras dengan anggota kelompoknya dalam mengumpulkan skor terbanyak. Tetapi, karena kerjasama yang kurang dari tiap-tiap kelompok mengakibatkan hanya 2 bahkan 1 orang yang mampu menjawab soal turnamen. Hal ini menunjukkan dalam pelaksanaan model pembelajaran kooperatif tipe teams games tournament (TGT) siswa yang aktif hanya siswa tertentu dan belum menyeluruh.

\section{SIMPULAN DAN SARAN}

Berdasarkan hasil penelitian diperoleh kemampuan awal siswa untuk kedua kelompok (kelompok eksperimen dan kelompok kontrol) adalah homogen yang ditunjukkan dengan $F_{\text {hitung }}<\mathrm{F}_{\text {tabel }}(1,06<1,72)$. Dan pada tes kemampuan akhir (setelah perlakuan) diperoleh thitung $<$ tabel $(1.626<2,000)$, sehingga yang diterima adalah $\mathrm{H}_{0}$ yang berarti model pembelajaran kooperatif tipe teams games tournament (TGT) tidak efektif untuk meningkatkan hasil belajar matematika materi program linear siswa kelas XI IPS SMA Negeri 8 Mataram.

\section{REFERENSI}

Adriyanto, Dewi Pramita, Abdillah, Syaharuddin, Mahsup, E. F. (2019). Peningkatan Kompetensi Strategis Siswa Melalui Model Pembelajaran Conceptual Understanding Procedures. Justek: Jurnal Sains Dan Teknologi, 2(1), 01-10. https://doi.org/https://doi.org/10.31764/justek.v2i1.3535

Aribawati, D., Kristin, F., \& ... (2018). Penerapan Model Pembelajaran Inkuiri Terbimbing Untuk Meningkatkan Kreativitas Dan Hasil Belajar IPA Siswa Kelas 3 SD. JUSTEK/ Jurnal Sains \& ....

Arikunto. (2006). Metode Penelitian. The A-Z of Social Research, 1, 160.

Arta Diantoro, S. B., Mahsup, M., \& Pramita, D. (2019). Penerapan Model Pembelajaran Kooperatif Tipe Two Stay Two Stray (TSTS) Dalam Meningkatkan Hasil Belajar Bentuk Aljabar Siswa Kelas VII SMP. Paedagoria / FKIP UMMat, 10(1), 01. https://doi.org/10.31764/paedagoria.v10i1.811 
Eka Fitriani, M. (2018). Pengaruh Pembelajaran Kooperatif Tipe Jigsaw Untuk Meningkatkan Pemahaman. Justek: Jurnal Sains Dan Teknologi, 1(2), 01-08. https://doi.org/https://doi.org/10.31764/justek.v1i2.3541

Habib Ratu Putra Negara, Syaharuddin Syaharuddin, Kiki Riska Ayu Kurniawati, A. A. (2019). Peningkatan Kompetensi Profesionalisme Guru Melalui Penerapan Edugame dan Eledu Berbasis Android. Proceeding National Conference: Education, Social Science, and Humaniora, 1(1), 85-87.

Mahsup, \& Anwar, Y. S. (2020). Development of structured modules to improve the mathematical understanding of the circle concept in class VIII Mataram 17 junior high school. Journal of Physics: Conference Series, 1465(1). https://doi.org/10.1088/1742$6596 / 1465 / 1 / 012074$

Mahsup, Abdillah, S. (2018). Peningkatan Penguasaan Konsep Lingkaran Dengan Metode Penemuan Bagi Mahasiswa. Paedagoria, 9(2), 91-96. Retrieved from http://journal.ummat.ac.id/index.php/paedagoria/article/view/871

Mahsup, M. (2011). Penerapan Stategi Inquiri Untuk Meningkatkan Hasil Belajar Tentang Sistem Persamaan Linear Dua Variabel. Beta, 4(2), 120-132. Retrieved from file:///C:/Users/Mahsup/Downloads/document (1).pdf

Mahsup, M., Ibrahim, I., Muhardini, S., Nurjannah, N., \& Fitriani, E. (2020). Peningkatan Hasil Belajar Mahasiswa Melalui Model Pembelajaran Tutor Sebaya. Jurnal Kependidikan: Jurnal Hasil Penelitian Dan Kajian Kepustakaan Di Bidang Pendidikan, Pengajaran Dan Pembelajaran. https://doi.org/10.33394/jk.v6i3.2673

Mandailina, V., \& Mahsup. (2018). Efektivitas Pembelajaran Matematika dengan Metode Thinking Aloud Pair Problem Solving (TAPPS) Terhadap Hasil Belajar Siswa Pokok Bahasan Kubus dan Balok Kelas VIII SMP/MTs. Jurnal Teori Dan Aplikasi Matematika (JTAM), 2(2), 144-147.

Muhardini, S., Rahman, N., Mahsup, M., Sudarwo, R., Anam, K., \& Fujiaturrahman, S. (2020). Pengembangan Media Pembelajaran Box Nusantara untuk Membentuk Kemampuan Memahami Konsep Tematik pada Siswa Sekolah Dasar. Jurnal Kependidikan: Jurnal Hasil Penelitian Dan Kajian Kepustakaan Di Bidang Pendidikan, Pengajaran Dan Pembelajaran, 6(2), 284. https://doi.org/10.33394/jk.v6i2.2612

Murtiah, B. (2018). Penerapan Pendekatan Kontekstual Menggunakan Media Gambar Binatang Untuk Meningkatkan Keterampilan Mendeskripsi Secara .... JUSTEK/ Jurnal Sains \& Teknologi.

Nurfiati, Vera Mandailina, Mahsup, Syaharuddin, A. (2020). Effect of Make A Match Learning Model on Student Learning Outcomes on Statistical Materials. Justek : Jurnal Sains Dan Teknologi, 3(1), 1-8. https://doi.org/https://doi.org/10.31764/justek.v3i1.3509

Puspita, M., Slameto, S., \& ... (2018). Peningkatkan Hasil Belajar Matematika Siswa Kelas 4 Sd Melalui Model Pembelajaran Problem Based Learning. Justek/ Jurnal Sains \& ....

Rahmatin, N., Pramita, D., Sirajuddin, S., \& Mahsup, M. (2019). Pengembangan Modul Pembelajaran Bangun Ruang Dengan Metode Creative Problem Solving (CPS) Pada Siswa Kelas VIII SMP. JTAM / Jurnal Teori Dan Aplikasi Matematika, 3(1), 27. https://doi.org/10.31764/jtam.v3i1.760

Setyowati, E., Kristin, F., \& Anugraheni, I. (2018). Penggunaan Model Pembelajaran Discovery Learning Untuk Meningkatkan Kreativitas Dan Hasil Belajar Siswa Kelas 5 SD Negeri Mangunsari 07. JUSTEK/ Jurnal Sains \& Teknologi, 1(1), 76-81.

Sulfemi, W. B. (2018). Penggunaan Team Games Tournament (TGT) Dengan Media Kartu Dalam Meningkatkan Hasil Belajar. Journal of Komodo Science Education, 1(01), 1-14.

Undang-Undang Republik Indonesia. (2003). Nomor 20 Tahun 2003. Tentang Sistem Pendidikan Nasional, (1), 1-26.

UURI, 20 tahun 2003. (2003). Undang-Undang Nomor 20 Tahun 2003 tentang Sistem Pendidikan Indonesia. Indonesia. 